\title{
Towards Effective Infrastructure Development in Nigeria: Theoretical Considerations from a Project Management Perspective
}

\author{
Ikechukwu A. Diugwu, Musa Mohammed, Dorothy L. Baba \\ Department of Project Management Technology, Federal University of Technology, Minna, Nigeria \\ Email: i.diugwu@futminna.edu.ng
}

Received 15 March 2015; accepted 11 April 2015; published 14 April 2015

Copyright (C) 2015 by authors and Scientific Research Publishing Inc. This work is licensed under the Creative Commons Attribution International License (CC BY). http://creativecommons.org/licenses/by/4.0/

(c) (i) Open Access

\begin{abstract}
A link exists between the level of investment in infrastructure and economic growth. However, it has been shown that in spite of huge amounts earmarked for infrastructural projects, the desired outcome/benefits are not attained in many cases. This has been attributed to poor adherence to project management principles in the conception, design, and execution of these projects. This paper highlights poor project conception and definition, poor budget and stakeholder management, as well as inadequate monitoring and evaluation as major causes of these failures. This can be minimized through the integration of good project management principles in the planning, design and execution of projects, supported by a robust monitoring and evaluation procedure.
\end{abstract}

\section{Keywords}

Project Management, Budget, Infrastructure, Public Sector, Projects, Economy, Economic Growth

\section{Introduction}

There are observations that a link exists between investment in infrastructure and economic growth, with several papers concluding that the effects of this link have been large [1]. For instance, Sarkar [2] opines that rapid industrial growth depends upon the availability of infrastructure such as electric power, road and rail transportation, and telecommunications. Economic infrastructure (or hardcore infrastructure), usually in the form of physical asset formation, comprises of activities that provide general facilities for carrying on economic activities. There are suggestions that the term infrastructure began to be used in development economics towards the end 
of 1950s [1]; however, its immediate predecessor, social overhead capital has been in use much earlier [3]. Jimenez [4], Jimenez [5] takes this view further by observing that infrastructure is often used synonymously with the term "social overhead capital," which according to Hirschman [6] encompass those

...services without which primary, secondary and tertiary production activities cannot function. In its wider sense it includes all public services from law and order through education and public health to transportation, communications, power and water supply, as well as such agricultural overhead capital as irrigation and drainage systems.

While the definition provided by Hirschman [6] seems to be restricted to facilities or services provided using public funds, the Associated General Contractors of America (AGCA) however views infrastructure as a nation's system of public facilities (whether publicly and privately funded), that ensures the delivery of essential services and a sustained standard of living; the base upon which society rests [7].

Cain [1] sees infrastructure as referring to the subordinate parts of almost every technological system-the track and terminals of a railway, the intakes and pumps of a waterworks, the wires and satellites of a telecommunications system. Infrastructure is categorized into economic (which includes irrigation, energy, transport, communications, banking, science and technology), and social overheads (health, hygiene and education) [2]. Further categorization of infrastructure is contained in [7]. In spite of the above categorization, this paper will focus more on the physical perspective of infrastructure than on its metaphorical connotations.

The contribution of infrastructure to national development cannot be over emphasized, and there are strong indications of a positive link between available infrastructural facilities and a nation's level of development. Hence, the view of infrastructure as a splendid parameter with which a nation's level of development could be judged. For instance, the industrial and agricultural revolutions that took place in England were accompanied by a corresponding revolution in transport and communication, high usage of coal and subsequently oil as a source of energy, tremendous expansion in financial institutions in order to finance production and trade, as well as a sudden increase of the knowledge of science and technology [2]. There are pointers to similar experiences in other countries. In India, roads infrastructure alone accounts for about $7 \%$ growth rate in total output of rural areas; and in Costa Rica, major businesses increased from 15 to about 86 due to tremendous rural electrification project [8].

Although the numerous benefits of infrastructure and the huge resources committed to infrastructural development are recognized, there are still some factors that militate against the early completion and at times successful execution of these projects. In Nigeria, Budget Office of the Federation (BOF), through its budget monitoring exercises, has identified some poor project portfolio management practices across Ministries, Departments and Agencies (MDAs), culminating in delayed compensations to local communities (with attendant disruptions to work), delayed payments to, and mobilization of contractors, delays in due process procurement and other approvals, among other factors that negatively impact on capital project execution in Nigeria. The budget implementation reports released by the BOF show that cost over-run, stalled projects, delayed approval for variations (in scope, design, duration, and cost), faulty design, inappropriate or delayed funding, poor stakeholder management (such as in management of compensations issues), are some of recurring factors that affect capital project execution in the country [9]-[12]. These are suggestive of poor project prioritization and conceptualization, as well as distortion of project implementation plans. These, individually or collectively, are inimical to successful project implementation.

\section{Effect of Infrastructural Development on National Development}

Infrastructure is the driving force of industrialization, as the availability of infrastructural facilities determines the nature of industrial development [13]. Hence, the suggestion by [2] that adequate and functional infrastructure enhances the industrial productivity of a country. Again, an extensive and efficient infrastructure is important in ensuring an effective functioning of the economy, with the quality and extensiveness of infrastructure networks (such as communications and transport) not only significantly impacting on the economic growth, but also affecting income inequalities and poverty in several [14].

The outcome of studies on the relationship between level of infrastructure and gross domestic product (GDP) suggests a positive association between the two. For instance, Servén [15] notes that $1 \%$ increase in the physical infrastructure of a country leads to between $1 \%$ and $2 \%$ growth in GDP. Other sources such as [16] contain a World Bank observation that a $10 \%$ rise in infrastructure assets directly increases GDP by up to a percentage 
point. On the other hand, insufficient/underdeveloped infrastructure impedes economic growth and social development worldwide. Along this line of thought, while [17] notes that poor infrastructure impedes on a nation's potentials for economic growth and international competitiveness, there is also a belief that insufficient infrastructure represents a major cause of loss of quality of life, illness and death [18]. Authors such as [19] argue that the net contribution of infrastructure to the economy is greater than the cost of its provision. Extending this argument, [20] observes that infrastructure impacts on the quality of life, wellbeing of the social system, and the sustained growth of economic and business activities because it enhances easy distribution of resources and essential services to the public. There are also views that investment(s) in infrastructure stimulates economic growth by increasing production facilities, reducing cost of transportation, and generating employments [21]. Also, [22] observes that better infrastructure leads to higher productivity of a country. Instances of the positive contribution of effective infrastructure to national economies abound [23]-[26]. In recognition of this level of contribution to economic growth, many national governments now place infrastructure projects high on their agendas [16], with current global project pipeline estimated at about \$9 trillion [27].

It is against this backdrop that this paper attempts to explore how the adoption and proper application of project management principles, especially by the public sector, could improve the planning, execution and monitoring of infrastructural projects, and ultimately enhance efficiency of infrastructural project delivery in Nigeria.

\section{The Concept of Project Management}

A project, to which infrastructural development activities belong to, involves competing demands with regards to scope, cost, risk and quality, often involving stakeholders with differing needs and expectations. And the fulfillment of mutually agreed objectives of any project requires the application of specialized knowledge, skills, tools, and techniques to project activities [28] [29]; this, in a nutshell, is what project management is all about.

Several attempts have been made to define/describe what project management connotes. For instance, authors such as [30] believe it is all about planning, scheduling and controlling those activities that impact on the achievement of project objectives. There are equally, definitions of project management given by professional bodies and regulators. The British Standard for Project Management defines project management as "the planning, monitoring and control of all aspects of a project and the motivation of all those involved in it to achieve the project objectives on time, and to the specified cost, quality performance" [31].

The Association for Project Management [29] notes that project management is the process by which projects are defined, planned, monitored, controlled and delivered such that agreed benefits are realized, by not only defining the inputs and outputs, but also taking into account all relevant constraints and mechanisms (Figure 1). It is evident from all these descriptions and views about project management that there must be a proper identification of needs, a commensurate execution plan of action, and measures to ensure conformance to this or modification of this as may be necessary. In order to meet stakeholder expectations and needs, and equally achieve project objectives, projects are usually executed through laid down procedures or processes- the project management processes (Figure 2).

These processes could be grouped into three major phases of planning, scheduling and controlling, described in Table 1, as itemized in [32].

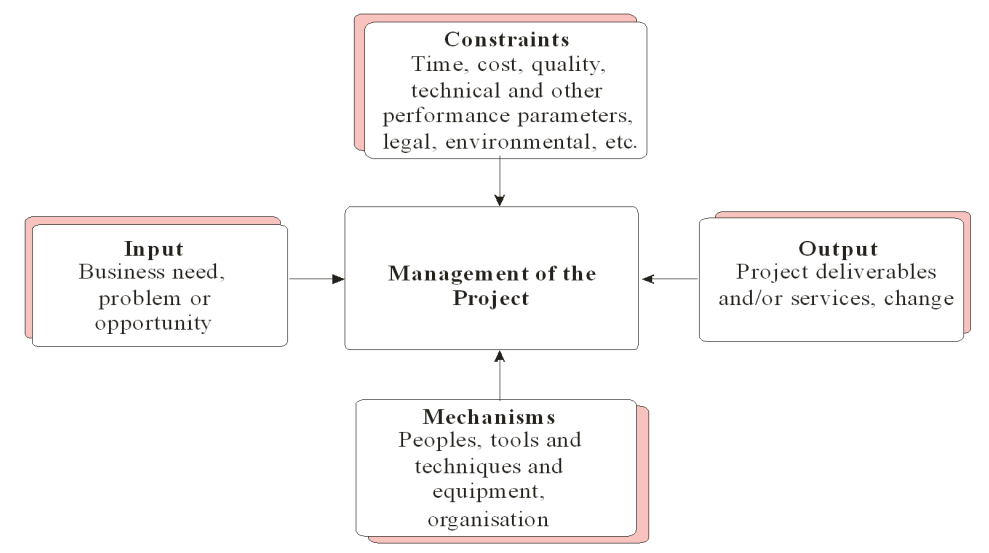

Figure 1. The project management process (source [29]). 


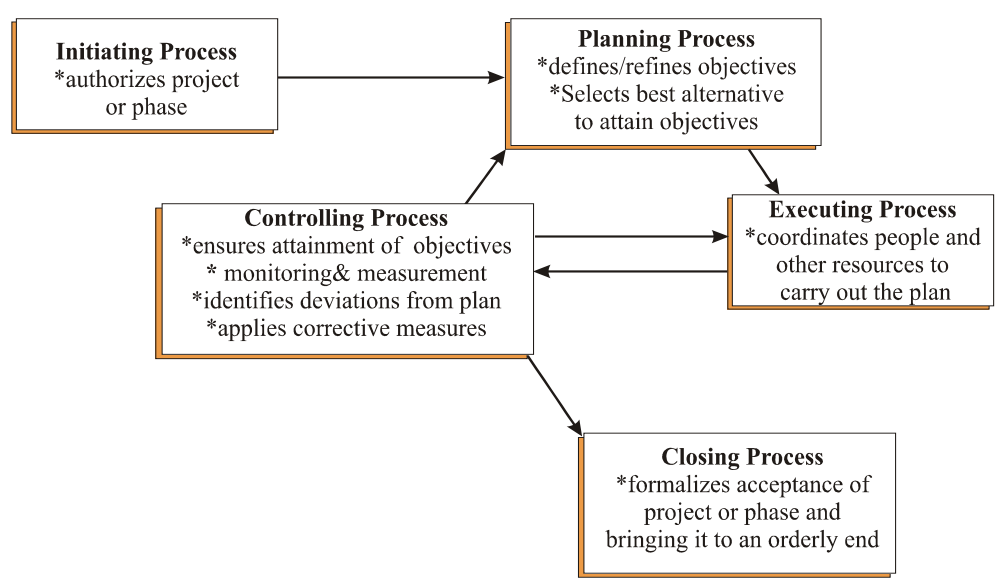

Figure 2. Project management processes (source [28]).

Table 1. Project management phases.

\begin{tabular}{|c|c|}
\hline Phase & Description \\
\hline Project planning & $\begin{array}{l}\text { Project planning, usually carried out before the commencement of a project, consists of } \\
\text { set of the plans and methods of project execution. It is concerned with identifying the activities } \\
\text { to be performed, and estimating the type and level of resources needed for this. In doing these, } \\
\text { there must be a strict adherence to the organization's rules, policies and procedure. }\end{array}$ \\
\hline Project scheduling & $\begin{array}{l}\text { This phase starts before the commencement of the project. It arranges project activities according } \\
\text { to the time that they should be performed, with a view to allocating resources as well } \\
\text { as allotting the start and finish dates to the various activities. This phase helps in identifying } \\
\text { critical tasks and shortage of resources that may affect effective project delivery. }\end{array}$ \\
\hline Project controlling & $\begin{array}{l}\text { Unlike the planning and scheduling phases, the controlling phase only becomes operational } \\
\text { during project execution. This phase is concerned with project monitoring in order to identify deviation(s) } \\
\text { from scheduled plan, and to addressing the bottleneck(s) so as to achieve effective project delivery. }\end{array}$ \\
\hline
\end{tabular}

Source: Gupta and Hira [32].

\section{Relationship between Project Outcome and Extent of Project Management Adoption}

Project management tools and techniques have been used to plan and control duration, cost and quality of projects, thus leading to successful project implementation [33]; and this has been described as more efficient than the traditional methods of management [34]. Success as used here is from the project management perspective; as there could be project management failures even in successful projects. Factors that lead to project failure have been extensively discussed [35] [36]. Avots [34] notes that prominent causes of failure include inadequate basis for project, the wrong choice of a project manager, an unsupportive top management, inadequately defined tasks, lack of project management techniques, misuse of management techniques, unplanned project closedown, as well as lack of commitment to the project. Again, [27] observe that infrastructure projects are affected by cost overruns, delays, failed procurement, or unavailability of private financing as shown in Table 2.

In Nigeria, the picture is not different. Data from the budget implementation reports released by the Budget Office show considerable cases of project delays, faulty designs, funding issues, budget overruns, as well as inefficient stakeholder management among other problems [9]-[12]. As observable from Budget Office of the Federation [12], the outer northern expressway (ONEX) LOT 1 project suffered from fund constraints and scope revision, and these may have been responsible for the extension of the contract duration; and in the expansion of airport expressway (LOT 1) project, there has been scope revision, delayed approval of application for modification of some contract terms, as well as a couple of duration extensions. Similar challenges have been observed at the Idu Industrial Area 1B engineering infrastructures development project, which has records of scope revisions, duration extension, increase in contract sum, as well as instances of compensation and resettlement issues [12]. 
Table 2. Project management phases.

\begin{tabular}{|c|c|c|c|c|c|}
\hline Example & $\begin{array}{l}\text { Budge } \\
\quad(€)\end{array}$ & $\begin{array}{l}\text { s actual } \\
\text { ion) }\end{array}$ & Delays and start-up problems & $\begin{array}{l}\text { Incorrect capacity and } \\
\text { revenue plans }\end{array}$ & $\begin{array}{c}\text { Total value lost vs } \\
\text { plan } \\
\text { (€ billion) }\end{array}$ \\
\hline Eurotunnel & 7.5 & 15.0 & $\begin{array}{l}\text { 6-month delay } \\
18 \text { months of unreliable } \\
\text { service after opening }\end{array}$ & 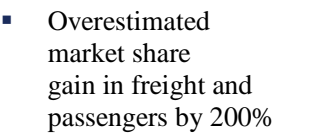 & $\sim 7.5$ \\
\hline $\begin{array}{l}\text { High-speed rail } \\
\text { Frankfurt-cologne }\end{array}$ & 4.5 & 6.0 & $\begin{array}{l}\text { - } 1 \text {-year delay of construction } \\
\text { - } \quad \text { issues }\end{array}$ & $\begin{array}{l}\text { Unforeseen } \\
\text { capped } \\
\text { government funding }\end{array}$ & $\sim 1.5$ \\
\hline $\begin{array}{l}\text { Betuwe line NL } \\
\text { (cargo rail) }\end{array}$ & 2.3 & $>5.0$ & $\begin{array}{l}\text { - } 1.5^{*} \text {-year delay of construction } \\
\text { fechnology choices still not } \\
\text { finalized }\end{array}$ & $\begin{array}{l}\text { Annual revenue } \\
\text { shortfall of } € 20 \text { million }\end{array}$ & $\sim 3.0$ \\
\hline $\begin{array}{l}\text { Kuala Lumpur } \\
\text { airport }\end{array}$ & 2.0 & 3.5 & $\begin{array}{l}\text { - Initial issues with connectivity } \\
\text { to downtown area } \\
\text { - Complaints about } \\
\text { facility hygiene levels }\end{array}$ & $\begin{array}{l}\text { Handles only } \sim 60 \% \text { of } \\
\text { current capacity } \\
\text { Losing market } \\
\text { share to Singapore }\end{array}$ & $\sim 1.5$ \\
\hline
\end{tabular}

"Some costs could be higher as some of the projects were not finalized when data were made available (source: [27]).

The foregoing discussions and observations would, perhaps, raise the issue of what "success" is and how it is measured in project delivery. Earlier works in project management and allied studies draw attention to the distinction between project success and project management success. For instance, [35] highlights a typical instance of a project management failure, even though a project seems successful. A clarification of this distinction could be found in [33], where it was noted that while project outcomes may meet the long term objectives, they may not meet the criteria of cost, time and quality; factors regarded as the three pillars of project management.

Figure 3 suggests that project management performance is judged based on the planning, production, and handover (stages 2 - 4) aspects of a project, whereas, the project success is assessed based on the outcome of stages $1-6$. Thus, it is important to note that the mere emergence of a product or service from a given project does not always translate to project management success.

A direct link has been made between the level of challenges encountered within a project's life cycles, and the level of integration of project management principles in the design and implementation of the project. The Budget Office of the Federation [10] for instance, observes that poor project conceptualization, design or planning practices by MDAs; poor project monitoring by MDAs; poor project status documentation; as well as poor projects ownership by local communities which often lead to the neglect of completed projects and a hostile attitude towards contractors are some of the factors that affect the smooth and successful execution of projects.. More succinctly, the Budget Office of the Federation [12] notes that "the sub-optimal implementation of MDA's

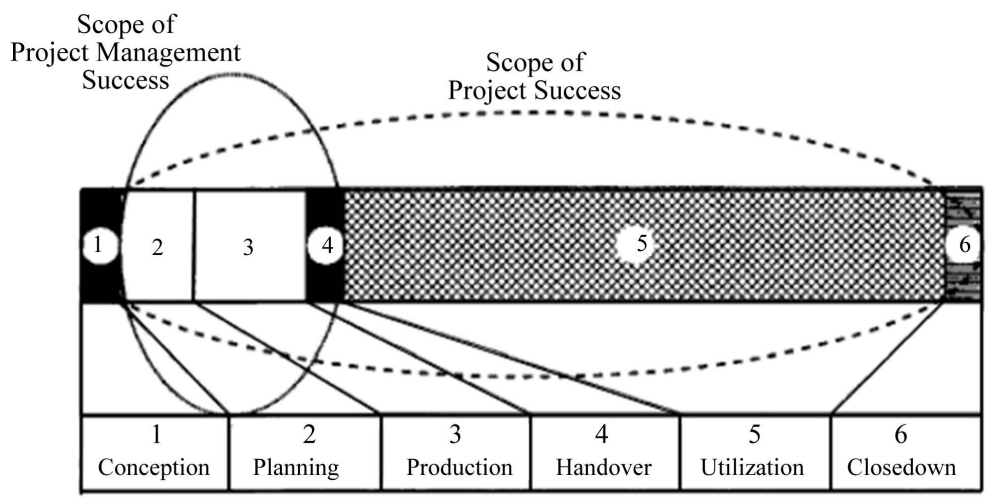

Figure 3. The scope of success within a project's life cycle (source [33]). 
capital projects is partly attributable to poor project management practices by some MDAs.”

These and similar factors can be adequately managed if certain factors are available. For instance, [37] believe that definite and realistic goals, level of competition, client satisfaction, degree of profitability, third party issues, market availability, the implementation process, as well as the perceived value of the project are some determinants of project success. Instances where projects management principles had been used to improve both the efficiency and effectiveness of project abound [38] [39]; perhaps through the minimization of problems associated with time and cost over-runs [40]. According to [41], project management endows project "overseers" and "undertakers" with skills needed to achieve efficient and effective project delivery through the adequate management of human and non-human resources available at their disposal. It is also suggested that the bidding and procurement processes, and ultimately, winning a bid is enhanced by a project management specialist, who has the requisite skills, knowledge and experience needed during contract formation process [42].

\section{Using Project Management Principles to Improve Infrastructural Project Delivery in Nigeria}

It has been noted that many public sector funded projects in Nigeria, have become largely uneconomical due to time and cost over-runs, attributable to several factors. Many of these are caused by choices made in the early stages of project development, which [27] observe may lead to incorrect forecasts and assumptions due to a limited understanding of market dynamics, an unwillingness to plan for volatility and adverse scenarios, as well as an overestimation of revenue and growth potential among other factors. This is closely related to the observation by [33] that poor project definition, attitude of client(s), as well as the extent to which projects are supervised, are major causes of project failures. These lapses, especially those identified by [33] are clearly noticeable in many public sector funded infrastructural projects in Nigeria [9]-[12].

These obstacles could be reduced or eliminated through adequate formulation, sound project organization, proper implementation planning, advance action, timely availability of funds, judicious tendering and procurement processes, better contract management, as well as effective management [40]. It has been put more generically as the proper planning, organizing, procuring, directing/leading, as well as controlling tasks associated with the project throughout its life cycle [41]. A further assessment of the problems associated with infrastructural projects in Nigeria as highlighted by the Budget Office of the Federation shows that the issue of scope management is at the forefront; hence the belief that many of these lapses could be addressed through proper project scope management.

Project scope management, according to the Project Management Institute [28], ensures the establishment of processes in a project such that all the work required and only the work required to complete the work successfully are included. An essential aspect of this is the project definition process which identifies the project scope, establishes project priorities, creates a work breakdown structure, and integrates same with the organization's overall business strategy [43]. The scope definition exercise ensures that a further evaluation of preferred solutions (agreed with sponsors and stakeholders), including the options required to achieve the solutions, is carried out. This culminates in a scope statement containing specific, tangible and measurable outcome(s) or deliverables of the project. Apart from focusing the project on successful attainment of its goals, it also serves both as a planning tool, and a measure for project success. It could be unequivocally stated that project definition and early decision making is critical to overall project success. Indeed, earlier studies, such as [44] suggest a positive correlation between the success of a project and clear scope definition. The application of project management principles would ensure that the project owner agrees with the objectives and deliverables (at each stage) as well as with the technical requirements. In line with [43], a complete scope definition should contain project objectives, deliverables, milestones, technical requirements, limits and exclusions, as well as reviews with customers. Furthermore, although the client is responsible for the identification of possible ideas for a project, project management facilitates this process by ensuring that a feasibility study, which identifies ideas (likely and unlikely to succeed) are established and brought to the notice of the client [33].

Even with a good project/scope definition exercise, the successful completion of the project could further be impeded by the actions or inactions of clients. It is evident from the various budget implementation reports of the Federal Republic of Nigeria that poor stakeholder management and inadequate funding are majors factors that affect the smooth execution of infrastructural projects. This highlights the need for better project procurement and cost management of public sector funded projects. 
Budget and cost management involve processes used in the estimating costs, setting agreed budgets, as well as in managing actual and forecast costs against that budget [29]. While this aspect entails efficient resource planning, cost estimation, budgeting, and control, it equally ensures that adequate consideration is given to the effect of project decisions on the cost of using the product of the project [28]. Through these processes, there is a higher stakeholder involvement in the management and awareness of project activities. Furthermore, a proper monitoring and control of cost against the budget, requires a proper recording and monitoring of amount of money needed to pay for orders that have been placed (commitments), payments yet to be made for work already done (accruals), as well as actual expenditure among others. Therefore, a good cost control measure facilitates the detection of variations from plans, and ensures that all approved changes (and only these) are documented in the cost baselines.

In all these, the role of the project manager in planning, executing, as well as managing the scope, human and material resources of the project cannot be overemphasized. For instance, it is the responsibility of the project manager to ensure that project objectives are specific, measurable, attainable, relevant and time-bound, and that the project is successfully completed. The role of competent project managers towards successful project completion has been acknowledged severally. A project manager has the requisite skills and qualities to effectively lead a project team, negotiate internally with management and externally with the client, maintain fiscal discipline with the project budget, adapt rapidly to change, ensure adherence to project timeline, and teach new team members how to work within the project's changing environment [45].

Thus, the problems associated with project design and execution (i.e. poor conception, faulty/poor design, client-contractor as well as employer-employee relationship, compensation issues. as well as financing gaps faced by stakeholders within a project's life cycle) could be minimized if the project owner should employ the services of a qualified project manager. This would, for instance, ensure the establishment of comprehensive planning and implementation framework that would highlight critical issues and design choices to be made, identify/highlight a set of practical approaches and tools that would facilitate decisions, as well as an implementation plan that ensures discipline throughout the life cycle of a project. Such a person, in ensuring adherence to proven procurement procedures, reduces project delays with the associated costs, and attendant diminished returns; additionally good project risk management becomes not only a major element of project selection, planning, and design, but also remains continuous process throughout the life cycle of the project.

\section{Conclusion}

This paper has undertaken a review of infrastructural projects. It highlighted the role of these projects in stimulating economic development, and identified some factors that militate against successful completion of projects. Using specific examples from Nigeria, it established a link between these project failures and non-adherence to project management principles. Based on this, it then suggested that good project conception and definition, proper cost and budget management, adequate stakeholder management, and the appointment of a competent project manager would go a long way in addressing the problems associated with delivery of public sector funded infrastructural projects in Nigeria.

\section{References}

[1] Cain, L.P. (1997) Historical Perspective on Infrastructure and US Economic Development. Regional Science and Urban Economics, 27, 117-138. http://dx.doi.org/10.1016/S0166-0462(96)02148-5

[2] Sarkar, S. (2009) Disparities in Infrastructure Development: An Inter-District Analysis of West Bengal State. The IUP Journal of Infrastructure, VII, 56-78.

[3] Greenwald, D. (1965) The McGraw Hill Dictionary of Modern Economics. McGraw-Hill, New York.

[4] Jimenez, E. (1994) Human and Physical Infrastructure: Public Investment and Pricing Policies in Developing Countries. World Bank Policy Research Working Paper Series (Working Paper Number 1281), World Bank, Washington DC.

[5] Jimenez, E. (1995) Human and Physical Infrastructure: Public Investment and Pricing Policies in Developing Countries. In: Behrman, J. and Srinivasan, T.N., Eds., Handbook of Development Economics, Elsevier Science, Berlin, 2774-2843. http://dx.doi.org/10.1016/S1573-4471(95)30020-1

[6] Hirschman, A.O. (1958) The Strategy of Economic Development. Yale University Press, New Haven.

[7] Hudson, W.R., Haas, R. and Uddin, W. (1997) Infrastructure Management. McGraw, New York.

[8] The World Bank (2013) Infrastructure. 
http://web.worldbank.org/WBSITE/EXTERNAL/EXTABOUTUS/0,,contentMDK:23262079 pagePK:51123644 piP K:329829 theSitePK:29708,00.html

[9] Budget Office of the Federation (2009) 2009 1st Quarter Budget Implementation Report. Federal Ministry of Finance, Abuja.

[10] Budget Office of the Federation (2010) Fourth Quarter and Consolidated Budget Implementation Report. Federal Ministry of Finance, Abuja.

[11] Budget Office of the Federation (2013) 2nd Quarter Budget Implementation Report. Federal Ministry of Finance, Abuja.

[12] Budget Office of the Federation (2012) 2012 Budget Implementation Report. Federal Ministry of Finance, Abuja.

[13] Sharma, V.K. and Vashist, R.L. (2010) An Evaluation of Infrastructure Development in the Hilly Areas. The IUP Journal of Infrastructure, 8, 38-50.

[14] World Economic Forum (2010) The Global Competitiveness Report 2010-2011. World Economic Forum, Geneva.

[15] Servén, L. (2010) Infrastructure and Growth. http://go.worldbank.org/TQMEWOD650

[16] Calderón, C., Moral-Benito, E. and Servén, L. (2009) Is Infrastructure Capital Productive? A Dynamic Heterogeneous Approach. World Bank Policy Research Working Paper Number 5682, The World Bank, Washington DC.

[17] The World Bank (2006) Infrastructure at the Crossroads: Lessons from 20 Years of World Bank Experience. The International Bank for Reconstruction and Development/The World Bank, Washington DC.

[18] Willoughby, C. (2004) Infrastructure and the Millennium Development Goals: Complementarity of Infrastructure for Achieving the Millennium Development Goals. United Nations, Berlin, 1-33.

[19] Esfahani, H.S. and Ramírez, M.T. (2003) Institutions, Infrastructure, and Economic Growth. Journal of Development Economics, 70, 443-477. http://dx.doi.org/10.1016/S0304-3878(02)00105-0

[20] Tang, S.M.T. (2006) How Front End Factors Affect Project Outcomes: A Look at Four Infrastructure Projects in Asia (Working Paper \#34). Collaboratory for Research on Global Projects, Stanford University, Stanford, CA.

[21] Sahoo, P., Dash, R.K. and Nataraj, G. (2010) Infrastructure Development and Economic Growth in China. IDE Discussion Paper No. 261, Institute of Developing Economies, JETRO.

[22] Akinyosoye, M. (2010) Infrastructure Development in Nigeria Road Map to Sustainable Development. Working Paper, Green Hill Technical Services Ltd., Lagos.

[23] Ahmad, R.I. and Malik, S. (2012) Rural Infrastructural Development and Economic Growth: A Time-Series: Evidence from Pakistan (1981-2010). Australian Journal of Business and Management Research, 2, 51-57.

[24] Imikan, A.M. and Ekpo, K.J. (2012) Infrastructure and Tourism Development in Nigeria: A Case Study of Rivers State. International Journal of Economic Development Research and Investment, 3, 53-60.

[25] Gold, K.L. (2011) Aggregate Analysis of the Impacts of Telecommunication Infrastructural Development on Nigerian Economy. 1st International Technology, Education and Environment Conference (TEEC2011), Omoku, 5-8 September 2011, 213-223.

[26] Olayiwola, L.M. and Adeleye, O.A. (2005) Rural Infrastructural Development in Nigeria: Between 1960 and 1990 Problems and Challenges. Journal of Social Sciences, 11, 91-96.

[27] Beckers, F., Chiara, N., Flesch, A., Maly, J., Silva, E. and Stegemann, U. (2013) A Risk-Management Approach to a Successful Infrastructure Project: Initiation, Financing, and Execution. McKinsey Working Papers on Risk, Number 52, McKinsey \& Company, New York. http://www.mckinsey.com/ /media/mckinsey/dotcom/client_service/Risk/Working\%20papers/52_A_risk-management _approach_to_a_successful_infrastructure_project.ashx

[28] Project Management Institute (2000) A Guide to the Project Management Body of Knowledge (PMBOK Guide). Project Management Institute, Newtown Square, Pennsylvania.

[29] Association for Project Management (2006) APM Body of Knowledge. Association for Project Management, Buckinghamshire.

[30] Modesto, S.T. and Tichapondwa, S.P. (2009) Successful Project Management: Insights from Distance Education Practices. Virtual University for the Small States of the Commonwealth, Vancouver.

[31] British Standards Institution (2010) BS 6079-1:2010_-Project Management: Principles and Guidelines for the Management of Projects. British Standards Institution, London.

[32] Gupta, P.K. and Hira, D.S. (2011) Operations Research. S. Chand and Company Ltd, New Delhi.

[33] Munns, A.K. and Bjeirmi, B.F. (1996) The Role of Project Management in Achieving Project Success. International Journal of Project Management, 14, 81-87. http://dx.doi.org/10.1016/0263-7863(95)00057-7

[34] Avots, I. (1969) Why Does Project Management Fail? California Management Review, 12, 77-82. 
http://dx.doi.org/10.2307/41164208

[35] de Wit, A. (1988) Measurement of Project Success. International Journal of Project Management, 6, 164-170. http://dx.doi.org/10.1016/0263-7863(88)90043-9

[36] Kerzner, H. (1989) Project Management: A Systems Approach to Planning, Scheduling, and Controlling. Van Nostrand Reinhold, New York.

[37] Morris, P.W.G. and Hugh, G.H. (1986) Preconditions of Success and Failure in Major Projects. Technical Paper No. 3, Templeton College, the Oxford Centre for Management Studies, Kennington.

[38] Oyedele, O.A. (2012) The Challenges of Infrastructure Development in Democratic Governance. FIG Working Week 2012 - Knowing to Manage the Territory, Protect the Environment, Evaluate the Cultural Heritage, International Federation of Surveyors, Rome.

[39] Amarasuriya, T.U. (2012) Balance Score Card—A Strategic Project Management Tool for Infrastructure Development Projects. Masters of Business Administration, University of Moratuwa, Sri Lanka.

[40] Chandra, P. (2009) Project Planning, Analysis, Selection, Financing, Implementation, and Review. Tata McGraw Hill Education Private Limited, New Delhi.

[41] Chitkara, K.K. (2009) Construction Project Management: Planning, Scheduling and Controlling. Tata McGraw Hill Education Private Limited, New Delhi.

[42] Okorafor, G.F. and Adu, E.T. (2010) Infrastructural Project Execution Drag and Integrated Development: Selected Cases in Nigeria. Interdisciplinary Journal of Contemporary Research in Business, 2, 557-569.

[43] Larson, E.W. and Gray, C.F. (2005) Project Management: The Managerial Process. McGraw-Hill/Irwin, Boston.

[44] Gobeli, D.H. and Larson, E.W. (1990) Project Management Problems. Engineering Management Journal, 2, 31-36.

[45] Boericke, K.M. (2003) What Is the Role of a Project Manager in Contract Research Organization? http://www.socra.org/pdf/200311_RoleOfProjMgrCRO.pdf 